grywali ważną rolę w kształtowaniu młodego człowieka. Autor, porównując poglądy pisarzy chrześcijańskich z poglądami autorów przedchrześcijańskich, ukazuje stopniową ewolucję poglądów w kierunku humanizacji relacji między rodzicami i dziećmi. Zauważa wszakże brak precyzyjnego określenia wychowawczych zadań ojca w analizowanych utworach. Rodzi się pytanie, czy rzeczywiście przytaczani autorzy nie dostrzegali potrzeby ukazywania tychże zadań ojca?

Ostatni IV rozdział publikowanej pracy doktorskiej, napisanej pod kierunkiem p. prof. J. Jundziłła z WSP w Bydgoszczy, poświęcił p. Kosznicki kształceniu instytucjonalnemu, stosunkowi autorów zachodniochrześcijańskich do szkoły i wykształcenia klasycznego oraz obrazom z życia szkolnego.

Plan pracy został starannie przemyślany i z logiczną konsekwencją rozpracowany. Poszczególne rozdziały, a nawet szczegółowe zagadnienia, kończy Autor podsumowaniem wyników analizy, a całość słusznymi i logicznymi wnioskami. Piszący sprawdza się jako dobry znawca przedmiotu, bazujący na tekście i wyprowadzający z niego ostrożne, ale trafne wnioski. Autor wykorzystuje szeroko materiał zawarty w dziełach autorów zachodniego chrześcijaństwa IIV wieku, bazując przy tym na literaturze przedmiotu. Prezentowana książka jest więc oryginalna, oparta na solidnej bazie źródłowej i opracowaniach; jest też nowatorska zarówno ze względu na dobry warsztat naukowy, jak i praktyczną przydatność rzetelnie omówionego problemu.

Ks. Augustyn Eckmann - Lublin.

\title{
Ks. Tadeusz KOŁOSOWSKI SDB, Od wolności wyboru wyznania do przymusu religijnego. Ewolucja pogladów biskupa Augustyna $z$ Hippony podczas schizmy donatystycznej $w$ Afryce Rzymskiej, Piła 2000, ss. 321.
}

Z uznaniem należy przyjąć rozprawę patrystyczną ks. T. Kołosowskiego. Temat pracy jest nader ważny i potrzebny. Wolałbym jednak w podtytule: „Ewolucja poglądów Augustyna, biskupa Hippony...”, bo Augustyn nie pochodził z Hippony, lecz z Tagasty, był natomiast biskupem Hippony.

Wiadomo, że św. Augustynem i jego dziełami interesowano się już za jego życia, i znany był na Zachodzie i Wschodzie. Wywarł ogromny wpływ na kulturę Europy, zwłaszcza na dalsze jej losy i życia Kościoła. W ciągu wieków powstało wiele cennych prac na temat jego osoby, pisarskiej spuścizny i nauki. Na tym polu nie pozostają w tyle również polscy uczeni. Literatura poświęcona doktrynie biskupa Hippony jest niezwykle bogata, tak pod względem ilości, jak i różnorodności poruszanej problematyki. Każda jednak nowa pozycja, zwłaszcza omawiająca myśl augustyńską w sposób słabo dotąd dostrzeżony, jest 
przyjmowana z ogromnym zainteresowaniem. Wydaje się, że taką właśnie jest recenzowana praca, która, poza wstępem (s. 7-17) i zakończeniem (s. 276-286), składa się z sześciu rozdziałów. W pierwszym z nich (s. 18-74) Autor ukazuje tło, kontekst historyczny dla badanych w kolejnych rozdziałach ewoluujących poglądów biskupa Hippony, przedstawia historię wydarzeń w Afryce Rzymskiej, genezę schizmy, narodowe i społeczne aspekty rozwoju donatyzmu, społeczne odniesienia pomiędzy donatystami a katolikami. Drugi rozdział (s. 75-107) ukazuje postawę cesarzy rzymskich i polityków wobec tego sporu.

W trzecim rozdziale (s. 108-157) przechodzi Autor in medias res: ukazuje pastoralną postawę Augustyna wobec donatystów, śledzi pisma biskupa Hippony, które świadczą o jego pokojowej i duszpasterskiej próbie oddziaływania na braci odłączających się. Autor wykazuje w świetle pism Augustyna miłość biskupa do błądzących, który pragnie pokonać błąd, a nie człowieka. Znakomicie przedstawia augustyńskie pojęcie tolerancji jako cierpliwe oczekiwanie na poprawę tego, którego się znosi. Stwierdza, że według Augustyna przebywanie $\mathrm{z}$ grzesznikami w duchu pokojowej tolerancji nie może przynieść szkody temu, kto sam nie dopuścił się grzechu (s. 137). Augustyn jest, jak sądzę, dla Autora w swych poglądach bardzo współczesny. Tolerancji towarzyszą i ją urzeczywistniają: caritas, unitas, pax. Augustyn dostrzega we wspólnocie katolickiej ludzi dobrych i złych. Tych ostatnich trzeba znosić aż do czasów ostatecznych. Przyczyną nietolerancji u donatystów jest brak u nich sprawiedliwości i pokory. Biskup Hippony podziela poglądy donatysty Tykoniusza, według którego dobrzy powinni tolerować złych w jedności ze względu na pokój, by oddzielić się od nich dopiero w dniu Sądu Ostatecznego. Ks. T. Kołosowski dobrze też przedstawił augustyńskie argumenty za tolerancją: biblijne, przykłady ludzi wielkich cieszących się autorytetem i osobiste doświadczenie życiowe biskupa Hippony. Własna droga Augustyna do Boga nie pozwala mu nawet pomyśleć o stosowaniu przemocy i przymusu. Nazwanie Augustyna „byłym heretykiem" (s. 156) uważam jednak za nieuzasadnione. Kiedy był bowiem manichejczykiem, nie mógł być heretykiem, bo nie był jeszcze chrześcijaninem sensu stricto. Słusznie natomiast stwierdza Autor, że Augustyn pragnął tak samo traktować innowierców, jak odnoszono się do niego, kiedy sam nie był chrześcijaninem. Postawę tolerancji wypełniał napominaniem, dialogiem, wspólnym poszukiwaniem prawdy.

W rozdziale czwartym (s. 158-190) słusznie Autor szuka odpowiedzi na zmianę stanowiska biskupa Hippony: od wolnego przez człowieka wyboru wyznania i tolerancji na ,compelle intrare”. Po gruntownej analizie augustyńskich pism i wydarzeń Autor wyciąga wnioski, iż prawdziwymi powodami, które wpłynęły na zmianę poglądów biskupa Hippony, były: jednogłośna niemal w tej materii opinia innych biskupów, okrucieństwa i przestępstwa donatystów oraz świadectwa osób nawróconych przy zastosowaniu przymusu. Augustyńskim uzasadnieniem przymusu religijnego zajął się ks. T. Kołosowski 
w rozdziale piątym (s. 191-252). Ukazał w nim, że teorię przymusu religijnego „compelle intrare” Augustyn oparł przede wszystkim na tekstach biblijnych Starego i Nowego Testamentu. Biskup Hippony kierował się dwoma kryteriami: miłością bliźniego i zbawieniem człowieka. Miłość zobowiązuje do niesienia pomocy heretykom także wbrew ich woli. Miłość każe użyć przymusu, jak to uczynił ojciec rodziny w ewangelicznej przypowieści o zaproszonych na ucztę. Zbawienie jest możliwe jedynie w jedności Kościoła katolickiego. Augustyn podkreśla pedagogiczne podstawy przymusu religijnego: correctio, wychowanie do prawdy i wpływ na dokonanie przez człowieka wyboru między dobrem a złem. Augustynowi chodzi o nawrócenie, a nie o pokonanie donatystów. Wysoko oceniam zebranie materiału, dobre analizy tekstu, wnioski. Czuję jednak pewien niedosyt w wykorzystaniu De correptione Donatistarum liber - listu 185, który napisał Augustyn na prośbę Bonifacego ok. 417 roku. List ten jest niezwykle ważny, bo stanowi rodzaj podręcznika faktów i argumentów rozwiniętych obszernie w długim sporze $\mathrm{z}$ donatystami. Autor dobrze przedstawił stosunek Augustyna do różnego rodzaju kar, popełnił jednak pewien lapsus, kiedy pisze, że w korespondencji Augustyna z Nektariuszem znajdujemy obszerne wyjaśnienie, jakie kary są dopuszczalne względem donatystów (s. 227). Nektariusz nie był donatystą, ale przedstawicielem inteligencji pogańskiej w Afryce. Korespondencja między św. Augustynem a Nektariuszem powstała na skutek wystąpień antychrześcijańskich 1 VI 408 roku w Kalamie. Na usprawiedliwienie Autora mogę dodać, że Augustyn pisał w liście 91,8 o niepokojach w Kalamie: ,contra recentissimas leges Kalendis Iuniis festo paganorum sacrilega sollemnitas agitata est... petulantissima turba saltantium in eodem prorsus vico ante fores transiret ecclesiae". Rewolta pogan była wykroczeniem „contra recentissimas leges”. Chodzi tu niewątpliwie o lex 19 de paganis i lex 43 de haereticis. Oba prawa zostały uchwalone równocześnie przez Honoriusza w Rzymie. W lex 19 de paganis znajdują się następujące przepisy: „Non liceat omnino in honorem sacrilegi ritus [...] exercere convivia vel quicquam sollemnitatis agitare”. Do tego właśnie fragmentu nawiązał Augustyn w liście 91, 8, kiedy pisał „sacrilega sollemnitas agitata est”, (zob. A. Eckmann, Dialog listowny św. Augustyna z Nektariuszem, RH 32:1984, z. 3, s. 57-94). Epistula 104, 1 i 104, 2.5 odnosi się także do pogan, a nie donatystów (s. 227, przyp. 1093 i 1098). Przekonywujące i jasne są analizy augustyńskich wypowiedzi odnośnie do kwestii i zastrzeżeń: przymus religijny a wolna wola oraz przymus religijny a rzeczywistość nawrócenia (s. 240-252). Autor wyciąga słuszny wniosek, że według Augustyna tylko ta wola jest wolna, która wybiera dobro i tylko taki człowiek może osiągnąć zbawienie.

Ostatni rozdział pracy (s. 253-278) stanowi całościowe spojrzenie na ewolucję poglądów Augustyna i jej przyczyny. Jeszcze raz w świetle różnych opinii współczesnych uczonych ocenia Autor augustyńską zmianę stanowiska i dochodzi do wniosku, że teorię przymusu religijnego, streszczającą się w „,com- 
pelle intrare”, tworzy Augustyn w związku ze sprawą donatystów. W zakończeniu (s. 279-286) jasno i wyraźnie podsumował ks. T. Kołosowski wyniki swoich badań.

A zatem układ pracy jest jasny, dokładnie podzielony, co rzuca się w oczy już przy spisie treści, a także stanowi ułatwienie dla czytelnika, bo staje się pomocne dla asymilacji i bogactwa materiału, zawartego w rozprawie. Rzetelnie potraktował Autor bazę wyjściową, dokumentując każdą swą opinię w odniesieniu do źródła. Uderza przejrzystość i jasność przekazu. Język pracy jest prosty i logiczny. Racjonalna treść jest komunikatywna. Autor swobodnie porusza się w źródłach i opracowaniach, przypisy nie są przeładowane odniesieniami do opracowań, do publikacji naukowych ustosunkowuje się krytycznie, ostrożnie polemizuje z poglądami uczonych, przedkłada własne poglądy, które są owocem jego studiów i przemyśleń. Rozprawa stanowi ważny wkład ks. T. Kołosowskiego w rozwój badań patrystycznych. Podsumowując recenzję rozprawy, chciałbym jeszcze raz podkreślić jej rzetelny poziom naukowy, odpowiedzialność Autora za ferowane sądy w oparciu o źródła i umiejętne posługiwanie się literaturą naukową.

Ks. Augustyn Eckmann - Lublin

\begin{abstract}
Michał STACHURA, Heretycy, schizmatycy i manichejczycy wobec cesarstwa rzymskiego (lata 324-428, wschodnia czesśc imperium), Kraków 2000, Towarzystwo Wydawnicze „Historia Iagellonica”, ss. 223.
\end{abstract}

Religijna polityka Konstantyna Wielkiego wyznaczyła nowy etap w stosunkach cesarstwa rzymskiego z Kościołem chrześcijańskim. Zacieśniająca się z biegiem czasu symbioza państwa i Kościoła miała epokowe znaczenie dla obu stron, obu przyniosła poważne korzyści, ale także przed obiema postawiła nowe dla nich problemy, których rozwiązania wymagało ich wzajemne współżycie. Problemów tych było oczywiście wiele, ale jednym $\mathrm{z}$ najważniejszych był ten, który generowały herezje i schizmy, rozdzierające od wewnątrz spoistość Kościoła Powszechnego. A ponieważ jedność Kościoła stała się od czasu przewrotu konstantyńskiego także sprawą państwa, przeto problem heretyków i schizmatyków, dotąd wewnątrzkościelny - dogmatyczny i dyscyplinarny, przybrał także charakter państwowy - prawny i polityczny. Stał się teraz wielowątkowym i przybrał na ciężarze gatunkowym. Nic więc dziwnego, ze od dawna przyciągał uwagę uczonych, którzy poświęcili mu już setki prac. Nie znaczy to jednak, aby zadawalająco odpowiedziano już na wszystkie pytania i wypełniono wszystkie luki. I to umożliwiło Michałowi Stachurze podjęcie badań nad tematem recenzowanej przeze mnie książki. 